January Meeting, 1909: The Automatic Electric Company installed in the lecture room one of their automatic telephone exchanges, and an address was delivered describing its operation.

February Meeting: Dr. W. S. Franklin, of Lehigh University, gave an experimental demonstration of the Gyroscope, and its application, with special reference to its use in the Brennan Monorail Car.

March Meeting: Mr. J. Kent Snith spoke on Vanadium and its application to the heavy arts; and Mr. Albert F. Shore described his Scleroscope.

April Meeting: The Underwood Typewriter was described.

May Meeting: Mr. William Tatham read an interesting paper on the Panama Canal.

June Meeting: Mr. W. H. Fulweiler read a paper on Surfacing of Roads.

The attendance at these meetings was somewhat better than in the previous year, but the value and interest of the subjects presented, and papers read, should attract a still larger attendance from members and their friends.

It is urged that members call attention to the meetings as widely as possible, and avail themselves of the privilege of sending tickets to friends. Also that they send to the Secretary lists of names of persons, associations and business houses likely to be interested, to assist the Secretary in making up mailing lists for notices and distribution of tickets.

Respectfully submitted,

James S. Rogriss.

Chairman.

Philadelphia, P.., Jamuary 6, ingo.

\title{
REPORT OF THE COMMITTEE ON SCIENCE AND THE ARTS.
}

To the President and Members of the Franklin Institute:

It is with pleasure that the committee on Science and the Arts submits the following account of its operation for the year ending September 30 . I909:

The total number of cases on the record books September 30, I909, was 60 , of which 33 were carried over from the previous years. Twentyseven new cases were added during the year. The number of cases disposed of during Ig09 was I5. The number of cases pending September 30, I909, was 70 . The list of awards is appended hereto.

The Sub-Committee on Reorganization reported early in the year with their recommendations for increasing the efficiency of the Committee's work. The consideration of this report occupied considerable time outside of the usual routine work of the Committee, requiring a number of special meetings in order to complete the work and pass it on to the Board of Managers for their information and approval. We submit herewith a copy of this report and ask the approval of the same. 
It is with great pleasure that the Chairman takes this opportunity to express his thorough appreciation of the faithful and loyal work done by his fellow members of the Committee.

Respectfully submitted,

JACOB Y. McConnel,

Chairman.

Philadelphia, Pa., Januaty 5, igio.

\section{APPENDIX.}

DETAILS OF AWARDS, ETC.

AWARDS OF THE EILIOTT CRESSON MEDAl.

2412. James Gayley for his "Dry Air Blast."

24I3. Mad. Sklodowska Curie and in Memory of Pierre Curie for their "Researches Resulting in the Discovery of Radium."

2445. Alexis Vernaz for his "Milling Files."

2446. Benjamin Talbot for his "Open Hearth Steel Process."

AWARD OF THE JOHN SCOTT LEGACY PREMIUM AND MEDAL.

2436. Frank J. Wetzel for his "Automatic Mechanical Stoker."

AWARD OF THE EDWARD LONGSTRETH MEDAL OF MERIT.

2430. B. Frank Teal for his "Anti-friction Universal Joint.

REPORTS MADE ADVISORY. $2400,2423,243$ I, 244I, 2449, 2453, 2460.

PROTESTS.

2400. Previous findings reversed, advisory.

2429. No award.

2430. Previous findings sustained.

REPORT WITHOUT RECOMMENDATION.

2428. 